\title{
Character Maturing in Storytelling: A Narrative Analysis of The New Found Commercial Short Film
}

\author{
Steven Saputra ${ }^{1}$ Riris Loisa ${ }^{1 *}$ \\ ${ }^{1}$ Faculty of Communication, Universitas Tarumanagara, Jakarta 11440, Indonesia \\ "Corresponding author. Email: ririsl@fikom.untar.ac.id
}

\begin{abstract}
Mass communication and media are widely used by creative workers for purposes. One example is online narrative advertising in a short film, titled The New Found (2013). The New Found tells the story of Andy, a man who must learn to let go of his hurt for the presence of a woman he loves. The characterizations narrated in this film encourage the topic to find out how the character maturation process and the narrative elements could be known through storytelling. This research uses a descriptive qualitative approach. Vladimir Propp's narrative analysis method was used to describe 7 Character Types and Propp's 31 Functions in the film's narrative. The narrative analysis of the short film The New Found is carried out on the character Andy who also takes place as a storyteller. This research's subject is the short film The New Found, while the objects are the scenes and narrative in it. Research data were collected by digital observation and documentation of scenes that featured storytelling and were sorted to dissect the narrative. This research result shows that The New Found's narrative treats its story as if it's an 'adventure' where Andy's character maturation process is depicted as he went through various incidents. Andy acts like a hero who has defeated his "opponent" and turned into a person who opened himself up to others. Even though Andy is pictured as an imperfect character, storytelling makes the audience more attached to the story because they could understand how the character feels. As a narrative advertisement, The New Found implements storytelling because it is considered capable enough to touch its consumer's emotional aspect, focused on building empathy for the story.
\end{abstract}

Keywords: Narrative analysis, advertising, storytelling, short film

\section{INTRODUCTION}

Film as a mass communication medium is a form of contemporary art that can convey messages aimed by its creators to the audience in audio-visual form. Quoting Kunata's statement [1], films can have various impacts such as entertainment, education, influence, and development for the audience. The effectiveness in carrying out these functions gives the impact for creators to produce films with various messages and values to be conveyed.

According to Sobur [2], issues can be conveyed with messages about objective reality and existing representations of that reality explicitly or impliedly through a film. Mass communication media development is utilized by creative industry workers to elevate their works in their respective domains. One example is an advertisement that is injected into a short film story. According to PPPI (Association of Indonesian Advertising Companies), an ad is a message that displays a product and is delivered through certain media that is financed by the initiator and addressed to the public [3].

As artistic works of art are required to present captivating story and visual elements, various types of films these days are often infiltrated by advertising messages by a brand that is intended to be delivered through its creators' ideas.
Advertising messages conveyed in short film stories are generally in the form of narrative tries to convey persuasive messages through its story to the audience without losing the essence of the short film itself.

The delivery of these advertisements is varied, some using product placement, others delivering their advertising messages through symbols or metaphoric dialogue in a film. Strengthening Rachmadini's statement [4], advertisements in the form of short films are generally made to convey persuasive messages, later to be published by the brand to a wider audience. His expertise in presenting stories using the image language made one of the most popular directors in Indonesia, Joko Anwar, collaborated with large companies to produce narrative advertisements in short film form. One of his commercial short films that is interesting to be studied in-depth is The New Found.

The New Found is a short film in collaboration between Joko Anwar and Toshiba Indonesia, released in 2013 with twelve minutes duration and published on Toshiba Indonesia's YouTube channel [5]. This short film tells the journey story of a man named Andy, played by Abimana Aryasatya. He keeps heart wounds from his childhood and must learn to open up and let go of the pain from his past for the presence of a woman who loves him, Maya, played by Bonita Lauwoie. 
Andy's character maturation is narrated through storytelling by himself and supported by visuals of events in his life that are full of color, texture, and appearance. The New Found is a concrete appreciation from Toshiba Indonesia and Joko Anwar for the grandeur of Indonesia's colors. The diversity of culture, nature, and professions of society represents Indonesia's multicultural wealth, also help telling stories to be closer to reality which signifies the journey of Andy's character in this short film.

This paper focuses on the journey of Andy's character that is delivered through storytelling. The way his character is described in the narrative makes this topic interesting to be used as research material. The researcher will use Vladimir Propp's narrative analysis method to dissect and describe the functions and types of characters through scenes and dialogues in this research. The narrative analysis will be taking the perspective of Andy, both the main character and narrator of the story. His scenes contain interesting aspects to study, such as thoughts, actions, and words. This research will focus on describing Andy's character and how his character develops.

\subsection{Our Contribution}

This paper presents some fresh thoughts based on theories and references proposed in related works. The research is conducted to determine the character development by dissecting the narrative in the short film The New Found using Vladimir Propp's narrative analysis technique, also to understand the use of storytelling as a tool in a narrative to deliver messages in commercial short films.

In one hand, this research is expected to be useful for Communication Science studies, specifically in narrative analysis and storytelling in mass communication media, as in a short film. This research is also expected to be reference material for other researchers' studies with similar issues, brings inspiration to be utilized by other readers in carrying out advertising activities.

On the other hand, this research is meant for researchers to implement theoretical knowledge that has been learned in Communication Science, as well as implementing knowledge that has been gained in advertising activities such as narrative development and storytelling in short films for future works.

\subsection{Paper Structure}

The rest of the paper is organized as follows. Section 2 introduces the theoretical basis and literature review used in this paper, includes theories, framework, and further explanation. Section 3 presents the research methods, data analysis stages, and data collection technique based on qualitative research rules. Then, the results of the research data analysis and discussion are described in Section 4. Finally, Section 5 concludes the research result and presents directions for future research.

\section{BACKGROUND}

\subsection{Film as Mass Communication}

Films are often described as moving or living images with stories presented in such a way for the audience [6]. Film in communication science is mainly defined as an audio-visual communication medium that aims to deliver a message to a group of people who gather in a certain place [7]. According to Wibowo [8], a film is a tool for delivering various messages to the general public through a story. The film is also defined as a medium of artistic expression for artists and cinema people to express and enliven the story and ideas they have in the form of real-life works. Wulandari once said, with pictures and sound, films can tell a lot in a short time. While watching a film, the audience seems to be able to penetrate space and time that can tell life lessons and even influence the audience [6].

According to Pratista [9], films can generally be divided into narrative elements and cinematic elements. The narrative element is the material or material to be processed, while cinematic is the method to process it. These two elements interact and synergize to form a film. In featurelength films, the narrative element is the treatment for its story, while cinematic elements are the technical aspects that construct the film [10]. Film as mass communication media is purposed to deliver messages in various forms and objectives, depending on the filmmaking's vision.

\subsection{Online Narrative Advertising}

According to Kotler \& Keller, Cravens and Piercy, Machfoedz, Shimp, Morrison, and Abdullah in Narita \& Suyanto [11], advertising is all forms of presenting information and promotions about organizations, ideas, goods, or services carried out by sponsors on an indirect basis, non-personal and requires payment. Advertising functions to attract attention, make profits and encourage audiences to make purchases and create feedbacks from consumers. Susanto stated, advertising is a packaging of information in the communication process that gets distributed to attract and influence the interest of a person, group of people, or anyone who wants to sell. The strength of advertising lies within its sophistication, expertise in formulating or organizing messages to attract attention and being able to build a shared meaning between the advertising message provider and the audience [12].

Online advertising is the term for advertisements placed on websites, search engines, or directories available through internet access that comes in various forms such as images, text, videos, interactive elements, and games [13]. According to Escalas [14], narrative advertising is a term for advertisements that tell a story. The narrative in an ad is arranged according to a series of events that been occurred chronologically and shows a causal relationship in its structure from one to another. Quoting Rachmadini [4], narrative advertisements uploaded on social media are usually packed in short film form, either stand-alone or divided into episodes such as web series. Narrative 
advertisements are packaged in various forms ranging from drama, comedy, and slice of life with hope, romance, and self-esteem themes. According to Wells [14], the audience observes ad messages through experiences or events in the story played by each character in a narrative advertisement in the form of a drama.

Narrative online advertising is formed by four elements; (1) Interactivity which is defined as the extent to which a person can act and react, whether influencing or being influenced, to a particular stimulus, (2) Vividness that is one of the most prominent attributes that contribute to the emotional response of consumers. (3) Entertainment that influences consumers to be attached to ad stories as a fun activity and stimulates affective responses by creating joy, and (4) Selfreferencing which is a cognitive process strategy to connect the information in ad watched and its importance to themselves furthermore make it a reference [15].

\subsection{Storytelling}

Storytelling is a way to communicate life experiences or events experienced by the storyteller by conveying and expressing their reactions to an incident, explaining the place and time, and captivating the audience using narration [16]. The storyteller will describe the place and time of the incident precisely to lure the audience to follow the story. These days, storytelling is widely used in narrative advertising that aims to strengthen a company's branding. This method is used because storytelling is more reliable than rational argument, statistics, and facts [17].

Storytelling is a form of communication that puts more emphasis on stories. Quoting McKee's statement, stories basically communicate how and why things change in life. A story is a substantial development that is anchored to a problem, which can bind the audience to feelings and understandings. Some goals that can be achieved through storytelling include: triggering activity, conveying identity, showing appreciation, encouraging people, sharing lessons, and inspiring people in the future [18]. The story told must represent the effective changes that have been implemented before. Opportunity must be given so the audience could imagine how the message delivered can be useful for their situation.

According to Bernard [19], storytelling is a good tool for collecting, analyzing and combining images with written text that have previously been assembled using conventional methods. As a branding tool, the storyline must represent the audience's attachment to the story as according to Kristensen [20]. Specific goals require the type of story that is relevant to the intended target audience. Every brand needs to place its consumers as audiences on a story adventure. As Li stated, stories should be used as a medium for delivering a brand's values and meanings [21]. Lindsay said there are seven pillars that companies or brands must pay attention to in communicating ad messages through storytelling, including (1) Emotion, (2) Plot, (3) Structure, (4) Voice, (5) Hero, (6) Villain and (7) Conflict. These seven pillars then form a storytelling style that describes how the message wants to be delivered by a company so it can be understood by its audience through text, images, or sound advertisements [20].

\subsection{Narrative}

Narrative is synonymous with story. Etymologically, narrative comes from the word "narre", which in Latin means "an attempt to tell something or event". Quoting Girard Ganette's statement [22], narrative is a combination of events used to tell something or can be defined as a representation of an event or series of events as the most important element. Furthermore, according to Eriyanto [22], narrative has basic characteristics. First, the events that exist are a series. Second, the sequence of events follows a certain logic, sequence, or cause and effect so it can be logically related. Third, in a narrative, events are not written completely, but there is a process of selecting and eliminating certain parts of the event to present a more coherent story. Narrative is only concerned of storytelling, how facts are told by presenting events into a narrative so it can be easier for the audience to follow.

Narrative analysis is an analysis conducted on narratives, both fiction and fact. Fictional narrative includes novels, fairy tales, poetry, films, music, comics, and other fictional writings. These are not only understood through verbal text form but also nonverbal or symbolic expressions. These forms have plot, role, and story character. Narrative is also often found in writing based on fact such as news, which certainly follows the characteristics of narrative [22]. Narrative analysis has several advantages so that it can be used as a tool for analyzing media texts and similar forms. First, narrative analysis helps understand how knowledge, meaning, and values are produced and disseminated in society. Second, narrative analysis understands how the social and political condition is told in a particular way, helping us to identify the dominant social strengths and values in society. Third, narrative analysis allows us to examine the hidden and latent aspects of a media text. Fourth, narrative analysis reflects continuity and change in communication [22].

Jannidis stated there is a characterization process in which the classification and naming of characters occurred in the narrative world [3]. Characterization gives attributes to the characters, through the narrator's explanation or the character's thoughts, actions, and words. Vladimir Propp found that characters in a story occupy a certain function in the narrative. With this, a narrative becomes full and coherent [22]. This function is conceptualized through two aspects. First is the characters' actions in the narrative and how these form certain meanings to be delivered. The second is the result of actions in the narrative. The actions of one character will affect the others.

\section{METHODS}

In this paper, researcher uses qualitative approach that aims to reveal a phenomenon in-depth and detail [23]. Descriptive research character is chosen because there is an issue that caught the researcher's attention, but there's no 
theoretical framework to explain it yet [24]. To sharpen this research, researcher uses Vladimir Propp's narrative analysis method to describe 31 Functions where each function has its own symbol, also to explain 7 Characters Type in the narrative [22].

The subject of this research is a short film ad titled The New Found which was released in 2013 with 11 minutes 55 seconds duration, written and directed by Joko Anwar. While the object under this research is the script and scenes in The New Found that focus on Andy's character and the storytelling he does.

The data collection methods used in this research are digital observation and documentation. The data analysis process used by the researcher in this research is inspired by
Sangsyarifsyah \& Aminudin [25] and will be carried out in several work steps:

1. Sorting out the scenes featuring Andy's narrative and visuals to be processed into narrative elements to be analyzed.

2. Analyzing the narrative elements using Vladimir Propp's analysis method, dissecting 31 Functions and 7 Character Types in the narrative.

3. Analyzing the data that has been obtained following the literature review that has been described previously.

4. Summing up the conclusion based on the data processing results that have been analyzed.

5. Presenting the research results descriptively.

Table 131 Narrative elements in the new found

\begin{tabular}{|c|c|c|c|}
\hline NO. & SYMBOL & FUNCTION & DESCRIPTION \\
\hline & $\alpha$ & Introduction & $\begin{array}{c}\text { The New Found narrative opens with the introduction of Andy as the } \\
\text { main character. }\end{array}$ \\
\hline 1. & $\beta$ & Absentation & $\begin{array}{l}\text { His life went well until his father left home. This tragedy made Andy's } \\
\text { life began to be disturbed. }\end{array}$ \\
\hline 2. & $\gamma$ & Interdiction & $\begin{array}{l}\text { Seeing his mother's condition, Andy forbids himself from having } \\
\text { someone. He is afraid that his father's incident might happen again. }\end{array}$ \\
\hline 3. & $\delta$ & $\begin{array}{l}\text { Violation of } \\
\text { interdiction }\end{array}$ & $\begin{array}{l}\text { When given the little blue blanket, Andy broke his own promise. He } \\
\text { became so attached to the little blue blanket. }\end{array}$ \\
\hline 8. & A & $\begin{array}{l}\text { Villainy and } \\
\text { lack }\end{array}$ & $\begin{array}{l}\text { A photographer accidentally took Andy's favorite blanket away. This } \\
\text { photographer acted like a 'criminal' who hurt Andy by took away his } \\
\text { favorite thing. }\end{array}$ \\
\hline 9. & B & Mediation & $\begin{array}{l}\text { Andy stopped crying when he saw his mother cried because of this } \\
\text { tragedy. After that, he started having nightmares again. }\end{array}$ \\
\hline 10. & $\mathrm{C}$ & Counteraction & $\begin{array}{l}\text { Andy promised himself not to had anything else. Andy was determined } \\
\text { to overcome the chaos in his life by overcoming his hurt. }\end{array}$ \\
\hline 11. & $\uparrow$ & Departure & $\begin{array}{l}\text { Andy grew up without significant events like the one in his childhood. } \\
\text { He has been keeping his promises. }\end{array}$ \\
\hline 12. & $\mathrm{D}$ & $\begin{array}{l}\text { The Donor } \\
\text { Sequence }\end{array}$ & $\begin{array}{l}\text { Andy left his old self being an adult. During this process, Andy was } \\
\text { accompanied by his friend Maya, who made Andy comfortable for a } \\
\text { long time. She acted like a helper to him. }\end{array}$ \\
\hline 13. & $\mathrm{E}$ & Reaction & $\begin{array}{c}\text { Andy was happy that they kept their relationship as friends. Andy felt } \\
\text { like Maya helped to keep his promise. }\end{array}$ \\
\hline 15. & $\mathrm{G}$ & Guidance & $\begin{array}{l}\text { Andy went to an art exhibition and saw his little blanket that was } \\
\text { contained in Maya's painting. }\end{array}$ \\
\hline 16. & $\mathrm{H}$ & Struggle & $\begin{array}{l}\text { This encounter was like Andy's struggle to fought his bad recalls. This } \\
\text { little blanket signified Andy's promise for not having anyone in his life. }\end{array}$ \\
\hline 25 . & M & Task & $\begin{array}{l}\text { Andy seemed to be forced to let go of his own promise, determining } \\
\text { whether he could forget his childhood hurt memories. }\end{array}$ \\
\hline 26. & $\mathrm{~N}$ & Solution & $\begin{array}{l}\text { When Maya came over him, Andy suddenly proposed to her, indicating } \\
\text { that Andy had let go of his hurt and proved himself as a hero. }\end{array}$ \\
\hline 27. & $\mathrm{R}$ & Recognition & $\begin{array}{c}\text { Maya was shocked and started to recognize Andy's character has turned } \\
\text { into a person who opens himself again. }\end{array}$ \\
\hline 29. & $\mathrm{~T}$ & Transfiguration & $\begin{array}{c}\text { Andy, who has been shutting himself off from others, now looks happy. } \\
\text { He looks amazed by all the events he has experienced. }\end{array}$ \\
\hline 31. & W & Wedding & $\begin{array}{l}\text { Andy's story ended up happily with Maya. Andy has become a more } \\
\text { mature person, and now he dares to have someone in his life again. }\end{array}$ \\
\hline
\end{tabular}

\section{FINDINGS AND DISCUSSIONS}

Each character in the story brings out their respective functions in the narrative to make the narrative comprehensive. According to Vladimir Propp, the function here refers to an action by a character that has been defined from the point of view of its significance as part of the character's actions in a narrative [22]. 
According to Eriyanto, the 31 Functions by Vladimir Propp are perfect stories, where every character and their function is contained in the story. However, a story mustn't contain all the Types and Functions in these characters, because it might be only a few parts of the character and function that stand out the most. In The New Found, there are only 17 narrative functions that have been found. The first three narrative functions affirm Andy as the center of The New Found's story. The opening clearly explains what happened to Andy and what his motivation is for taking action throughout the rest of the story.

Andy's encounter with his blanket becomes the culmination of his character development in The New Found's narrative. This narrative shows the character maturing that happened to Andy at the end of The New Found story. As Santrock stated [26], adulthood is a period of shifting egocentric views into empathetic attitudes, where individuals create and establish interpersonal relationships with others. Andy manifested himself as an "adult" by opening himself up for relationships with others and putting his egocentricity aside. As a complement to Vladimir Propp's 31 Functions, there are 7 Character Types in the narrative. Each character has a specific function in a story. From Andy's role in The New Found, several characters can be found that match with character types that Vladimir Propp invented.

The New Found proves that a character maturing process can be conveyed through a narrative centered on Andy as the main character. The narrative that Andy tells to the audience shows the character development he experiences through his own perspective. The most important parts of The New Found are accompanied by Andy's visuals and narrative, rarely involving other characters and dialogue. Even if there are scenes of Andy with other characters, the dialogue is intended to strengthen and describe Andy's character. Andy's words and actions are the ones that drive The New Found's story. Andy brings the audience to share his experiences through incidents, and how he responds to them.

The audience is taken to follow Andy's journey as a hero figure who lost his beloved ones, kept the promise that he has been holding since a child, got help from Maya, and fought his heartbreak when he saw his little blanket again. By following these events, the audience should be able to understand how Andy's character has grown to be more mature at the end of The New Found story through the narrative in Andy's storytelling.

Quoting Rahayu, in the narrative paradigm, there is an assumption that telling and listening to stories is one basic part of essential human nature [27]. Story messages are easier to understand and remember when delivered through a narrative. Storytelling is an effective tool to use if the story to be told is chosen smartly. Through storytelling, the storyteller can trigger responses and communicating who he is to the listener [18]. This is what The New Found applied.
Andy's storytelling shows his pure character and how he deals with the existing problems. Although his manner can't be completely justified, the audience can understand the heartbreak and reasons why Andy's character is the way he is. This can happen because The New Found's narrative focuses on Andy's character struggle with his hurt, despite his imperfections. The purpose of storytelling in The New Found is not to tell the greatness of Andy's character, but to engage the audience to listen to the story of Andy's trying to free himself from old hurts together.

\section{CONCLUSIONS}

Based on the research results, it is known how the character maturing process is conveyed through storytelling in the short film ad The New Found. Storytelling becomes the narrative's foundation centered on Andy as the main character of the story, and other characters take places as supporters to strengthen Andy's narrative. The conclusion of the discussion in this research indicates that The New Found's narrative treats its story as if it's an 'adventure'. Andy becomes the hero that has gone through various defining moments and met other characters who have influenced his character throughout the story. At the end of the narrative, Andy experiencing character development just like a hero who defeated his enemy after all the incidents he went through in the story. Character maturing happened to Andy. He changed from being such a close off person to someone that opens himself up to others again.

Even though the characters are pictured imperfect with flaws in their behavior, storytelling makes the audience more attached to the story thanks to the narrative that treats them to understand how the character feels. Storytelling is considered to be more capable of creating an emotional bond between the audience and the story. Same as its identity as a narrative advertisement, The New Found implements storytelling because it is considered more capable of touching the emotional aspect of the audience to follow the story progression rather than highlighting the brand (Toshiba Indonesia) behind the making of this advertisement itself.

This research focuses more on examining the narrative element and not exploring characters' interaction in depth. The researcher hopes that there will be research based on semiotic analysis regarding the meaning of Andy's character towards the small blanket in The New Found for days to come. The character's development pictured in The New Found is also able to create a strong emotional impact for the audience. This means it is important to pay attention to character writing in short films, which becomes a lesson for writers in developing great characters for narrative writing. 
Table 2 Character types in the new found

\begin{tabular}{ccc} 
CHARACTER & ROLE & FUNCTION IN THE STORY \\
\hline The Villain & Photographer & $\begin{array}{c}\text { The photographer accidentally took Andy's little blue blanket. His sloppy } \\
\text { act made Andy feel sad and hurt Andy's heart even though he wasn't } \\
\text { actually bad. }\end{array}$ \\
The Helper & $\begin{array}{c}\text { Fabric shop } \\
\text { owner }\end{array}$ & $\begin{array}{r}\text { The fabric shop owner gave Andy a small blanket. This gift comforted } \\
\text { Andy. Even though it was lost once, this small blanket surprisingly became } \\
\text { an 'aid' for Andy in healing his hurt later in the story. }\end{array}$ \\
The Hero & $\begin{array}{r}\text { Maya has become a loyal friend that accompanied Andy and helped him } \\
\text { by keeping their relationship comfortable. By accident, Maya found Andy's } \\
\text { little blue blanket. This surprising incident helped Andy in healing his hurt. } \\
\text { Little Andy was hurt by losing his beloved little blue blanket. This tragedy } \\
\text { made Andy closed off himself from others for a long time. After he got } \\
\text { help and support from other characters, Andy successfully defeated the } \\
\text { struggle in his heart at the end of the story. }\end{array}$ \\
\hline
\end{tabular}

\section{ACKNOWLEDGMENT}

This work was supported by Universitas Tarumanagara.

\section{REFERENCES}

[1] H.R. Kunata, Kekerasan dalam film The Raid 2 (analisis isi film The Raid 2 karya Gareth Evans), Thesis, Department of Communication Science, University of Muhammadiyah Malang, 2018. URI: http://eprints.umm.ac.id/id/eprint/53791

[2] A. Bimantoro, Representasi peran gender dalam film drama romansa (analisis semiotika Roland Barthes pada film Love for Sale), Thesis, Faculty of Communication and Diplomacy, Pertamina University, 2020. URI: https://library.universitaspertamina.ac.id//xmlui/handle/ $123456789 / 2147$

[3] M.C. Umam, Analisis naratif perempuan sebagai karakter utama pada iklan produk laki-laki, in: R.S. Kusuma (Eds.), Petanda : Jurnal Ilmu Komunikasi dan Humaniora, vol. 1(2), 2019, pp. 75-89. DOI: https://doi.org/10.32509/jhm.v1i2.830

[4] N. Rachmadini, Pengaruh iklan online naratif Move On Trip terhadap sikap penonton media sosial YouTube, in: G. Khalisha (Eds.), Petanda : Jurnal Ilmu Komunikasi dan Humaniora, vol. 1(2), 2019, pp. 90-96. DOI: https://doi.org/10.32509/jhm.v1i2.831

[5] Toshiba Indonesia, The New Found, 2013. URL: https://youtu.be/iSFpSSkltW8

[6] P. Wulandari, Analisis naratif film "Nightcrawler" mengenai ideologi kejurnalistikan (metode penelitian kualitatif dengan analisis naratif menggunakan teori
Seymour Chatman), Thesis, Faculty of Communication Science, Bandung Islamic University, 2016. URI: http://hdl.handle.net/123456789/12951

[7] O.U. Effendy, Ilmu Komunikasi Teori dan Praktek (28 ${ }^{\text {th }}$ edition), PT. Remaja Rosdakarya, 2017.

[8] F. Wibowo, Teknik Program Televisi, Pinus Book Publisher, 2006.

[9] H. Pratista, Memahami Film, Homerian Pustaka, 2008.

[10] S. Emalya, Analisis naratif ekranisasi novel "Supernova: Ksatria, Putri, dan Bintang Jatuh" ke dalam bentuk film, Thesis, Faculty of Recording Media Arts, Indonesia Institute of The Arts Yogyakarta, 2017. URI: http://digilib.isi.ac.id/id/eprint/2987

[11] M.G. Narita, Persepsi audiens terhadap iklan soft selling dan hard selling Toyota New Yaris di YouTube, Thesis, School of Social Sciences, University of National Development "Veteran" Yogyakarta, 2019. URI: http://eprints.upnyk.ac.id/id/eprint/20247

[12] E.H. Susanto, Dinamika pesan iklan, Jurnal Komunikasi, vol. 6(2), 2014, pp. 1-9.

[13] R. Stokes, eMarketing: The Essential Guide to Marketing in A Digital World ( $5^{\text {th }}$ edition), Quirk, 2013.

[14] S. Rodgers, E. Thorson, Advertising Theory, Routledge, 2012.

[15] R.K.H Ching, P. Tong, J.S. Chen, \& H.Y. Chen, Narrative online advertising: identification and its effects on attitude toward a product, Internet Research, vol. 23(4), 2013, pp. 414-438. DOI: https://doi.org/ 10.1108/IntR-04-2012-0077 
[16] D. Hazizah, M.T. Lestari, \& A.I. Imran, Analisis tiga perubahan komunikasi pemasaran melalui iklan (studi kualitatif pada iklan naratif online "LINE - Nic and Mar"), eProceedings of Management, vol. 3(2), 2016, pp. 2512-2516.

[17] B. Kaufman, Stories that sell, stories that tell: effective storytelling can strengthen an organization's bonds with all of its stakeholders (Communication), Journal of Business Strategy, vol. 24(2), 2003, pp. 11-16.

[18] S. Denning, Telling tales, Harvard Business Review, vol. 82(5), 2004, pp. 122-129. URI: https://hci.stanford.edu/dschool/resources/storytelling/T elling\%20Tales\%20HBR.pdf

[19] Siswantini, G. Mahestu, A.N. Rahmani, Interpretasi digital storytelling pada iklan Tokopedia, Journal Digital Media \& Relationship, vol. 1(1), 2019, pp. 1-10. URI: http://ejurnal.ars.ac.id/index.php/jdigital/article/view/15 9

[20] F.A. Trisakti, H. Alifahmi, Destination brand storytelling: analisis naratif video The Journey to A Wonderful World Kementerian Pariwisata, Jurnal Komunikasi Indonesia, vol. 7(1), 2018, pp. 73-86. DOI: https://doi.org/10.7454/jki.v7i1.9692

[21] M. Li, Narrative advertising, Thesis, Department of Mass Communication, East Tennessee State University, 2015. URI: https://dc.etsu.edu/etd/2485/

[22] Eriyanto, Analisis Naratif: Dasar-dasar dan Penerapannya dalam Analisis Teks Berita Media (1 ${ }^{\text {st }}$ edition), Kencana Prenada Media Group, 2013.

[23] R. Sani, Analisis naratif peran bapak dalam film Sabtu Bersama Bapak, Thesis, Department of Islamic Broadcasting Communication, Syarif Hidayatullah State Islamic University Jakarta, 2019. URI: http://repository.uinjkt.ac.id/dspace/handle/123456789/ 40410

[24] H.F. Zein, Analisis naratif pada film dokumenter Alkinemokiye produksi Watchdoc, Thesis, Department of Journalistic, Syarif Hidayatullah State Islamic University Jakarta, 2020. URI: http://repository. uinjkt.ac.id/dspace/handle/123456789/52198

[25] M.F. Sangsyarifsyah, A. Aminudin, Representasi tentang cinta melalui tokoh Richard dalam film "Love for Sale" (analisis semiotika Charles Sanders Peirce), Komunikasiana: Journal of Communication Studies, vol. 2(1), 2020. URI: http://ejournal.uinsuska.ac.id/index.php/komunikasiana/article/view/9389
[26] D.I. Lestari, I.M. Agung, Empati dan pemaafan pada mahasiswa fakultas psikologi UIN Suska Riau, Jurnal Studia Insania, vol. 4(2), 2016, pp. 137-146. DOI: https://dx.doi.org/10.18592/jsi.v4i2.1126

[27] W.S.B. Rahayu, Penggunaan storytelling dalam iklan LINE Webtoon pada sikap pengguna, Thesis, Faculty of Economics and Business, Brawijaya University, 2017. URI: http://repository.ub.ac.id/id/ eprint/2974 